\title{
Sustainable forest development in the Styrian Eisenwurzen Nature and Geopark and beyond
}

\author{
Oliver Gulas, Veronika Frank \& Christoph Nitsch
}

Keywords: Nature Park, Geopark, protected area, Eisenwurzen, old-growth forests, stepping stones, connectivity

\begin{abstract}
With $62 \%$ of its total area covered in forest, Styria is the most densely forested province in Austria. Accordingly, forests, more than any other habitat, characterise the landscape in the Styrian Eisenwurzen Nature and Geopark. The forest areas of the nature park are managed by a combination of private owners and the Styrian Provincial Forests, the Austrian Federal Forests and the City of Vienna. The near-natural areas of the nature park forests in particular are characterised by species-rich fauna and flora, which include specially protected species. However, the forests of the nature park do not simply provide habitats for a large number of protected animal and plant species. Due to their location - embedded between the Dürrenstein wilderness area, the Kalkalpen National Park and the Gesäuse National Park - they also function as important stepping-stone habitats for many forest-bound species.
\end{abstract}

Profile

Protected area

Nature Park \& Geopark

Eisenwurzen

Mountain range

Alps, Austria

\section{Introduction}

\section{What is a Nature Park in Austria?}

The core of any Nature Park $(\mathrm{NaP})$ is always a protected landscape (e.g. a Natura 2000 site), and it can also be shaped by centuries of farming or forestry activity. This means that a $\mathrm{NaP}$ is not simply an area with an intact landscape; it can also include alpine or orchard meadows, for example. In addition, these landscapes can have high biodiversity. The protection and promotion of biological diversity are particular concerns of the NaPs in Austria. Austria's $47 \mathrm{NaPs}$ protect a variety of landscapes, which are characterized by their natural and cultural heritage and a wide range of possibilities to experience nature. The total area of all Austrian NaPs is around 500000 ha $(6 \%$ of Austria's total area).

The main objective of NaPs is landscape protection in connection with their sustainable use. The Parks have four main remits (VNÖ 2021):

- Environmental protection.

- Education.

- Regional development.

- Tourism.

Jointly, these all play an important role in strengthening the $\mathrm{NaP}$ itself: involving local communities and visitors enhances their perception and acceptance of the Park while also helping to protect the Park's unique landscapes for future generations.

\section{What is a Geopark?}

Every UNESCO Global Geopark has unique features, and offers visitors landscapes and sites of international geological significance to enjoy. The main goals of geoparks are protection, education and sustainable development as a base for sustainable tourism

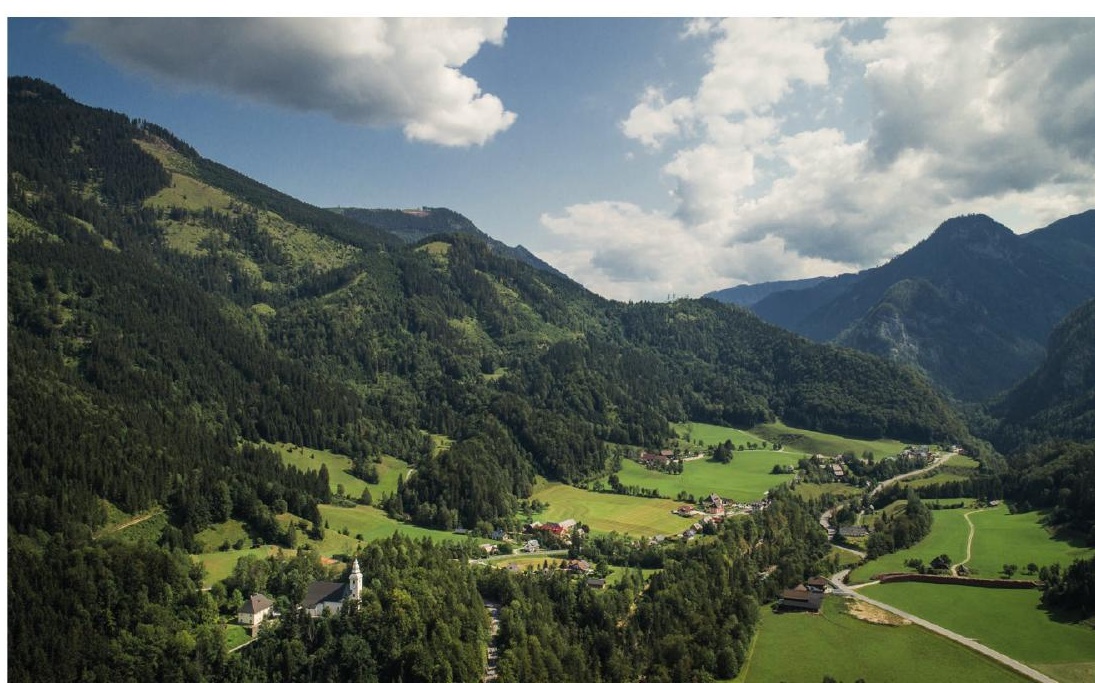

Figure 1 - Typical Landscape of the Styrian Eisenwurzen Nature and Geopark (C) Stefan Leitner-Gesaeuse - Mit Unterstützung von Bund, Land und EU (LEADER)

(Pásková 2012; Dowling 2013; Dowling \& Newsome 2006).

A geopark is not only about geology. According to the Global Geoparks Network (2020), one role of a park's management is to use geological heritage in connection with the area's natural and cultural heritage to increase awareness and understanding of key issues facing society in the context of the dynamic planet we all live on (e.g. climate change, or reducing the impact of natural disasters). In addition, local people's involvement in a geopark strengthens their identification with the region, while joint sustainable tourism projects, working with other local people (e.g. as a Geopark ranger), or partner networks targeting local food production, all help to raise awareness of the park and its aims. Through regional development, the geoparks 


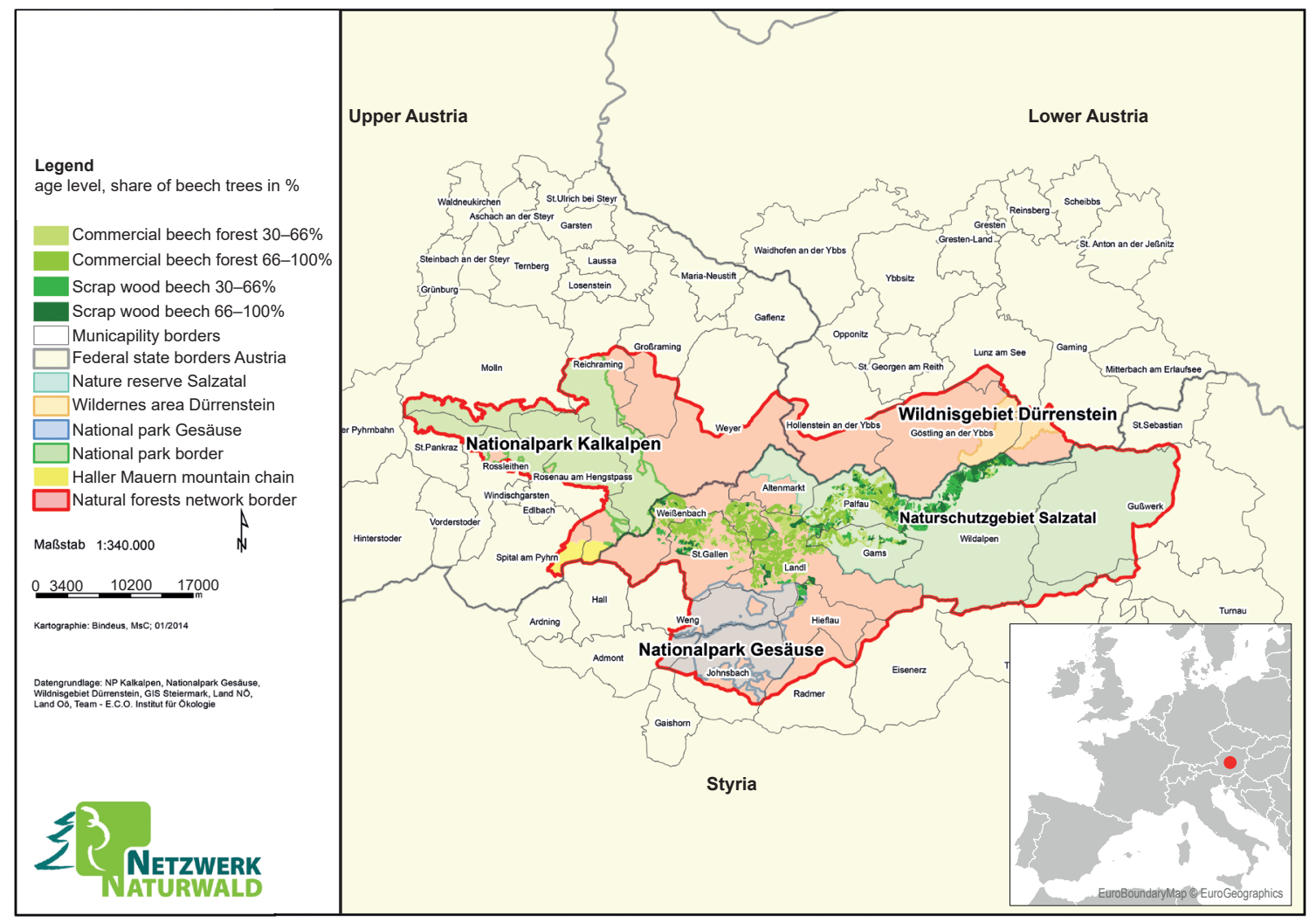

Figure 2 - Map of the Natural Forests Network project area. (C) E.C.O.

are creating innovative local enterprises, new jobs and high-quality training courses (Dowling \& Newsome 2006), and offer sustainable geotourism (i.e. tourism focused on actively discovering Earth's heritage).

In 2004, 17 European and 8 Chinese Geoparks came together to form the Global Geoparks Network. Today, this network has 161 members in 44 countries, which "have become an increasingly important tool for UNESCO to engage Member States and their communities in the Earth Sciences and geological heritage. During the $38^{\text {th }}$ session of UNESCO's General Conference in 2015, the 195 Member States of UNESCO ratified the creation of a new label, the UNESCO Global Geoparks"' (Global Geoparks Network 2017).

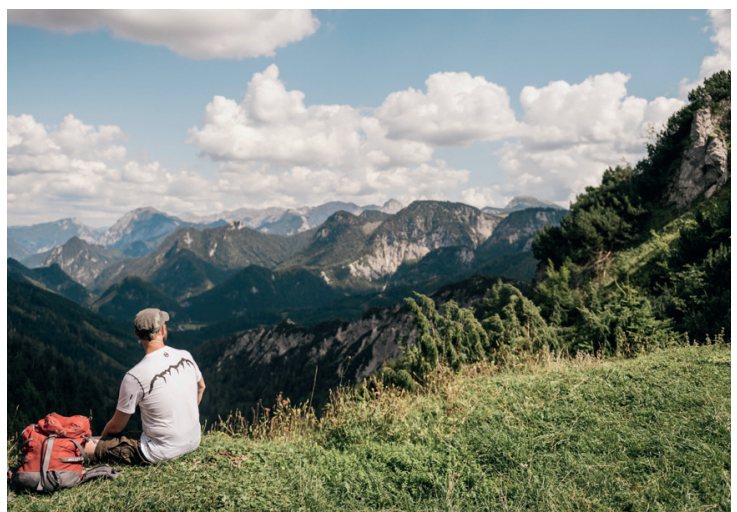

Figure 3 - Mountain and forest area of the Styrian Eisenwurzen Nature and Geopark (C) Stefan Leitner - Gesaeuse - Mit Unterstützung von Bund, Land und EU (LEADER)
The basic characteristics of the Styrian Eisenwurzen Nature and Geopark

The Styrian Eisenwurzen UNESCO Global Geopark is located in the northern part of Upper Styria, in the heart of Austria, where the three federal states of Lower Austria, Upper Austria and Styria meet. The Nature and Geopark covers an area of $586 \mathrm{~km}^{2}$, encompassing the municipalities of Altenmarkt, Landl, St. Gallen and Wildalpen (Figure 2).

Forest-covered mountains, cultivated landscapes in broad valleys, villages on river terraces and deeply incised riverbeds surrounded by the limestone mountains of the Hochschwab and the Gesäuse are characteristic of the region (see Figure 1, $3 \& 5$ ). Given the area's natural and climatic conditions, grassland agriculture with dairy farming and forest management are predominant. Meadows, fields and orchards are characteristic of the cultivated valley landscapes. Forests are found only at locations which are unsuitable for agricultural use, such as steep slopes. The forest is the main habitat type in the Nature and Geopark.

\section{The Past. The history of the Styrian Eisen- wurzen}

The area surrounding the Styrian Erzberg mine is called Eisenwurzen. Originally, the name was limited to the location of the iron ore deposit. However, in the $18^{\text {th }}$ century, it spread to include all areas processing iron. Smaller ore deposits were discovered during the same century, as at Arzberg near Wildalpen, which 
is also part of the Nature and Geopark. Along with the iron, charcoal and hydropower provided the basis for numerous hammer mills in the region. So-called lords in charge of hammer mills (Hammerherren), charcoal burners and raftsmen had a huge influence on the region during the golden age of the Eisenwurzen, in the $15^{\text {th }}$ and $16^{\text {th }}$ centuries, when the ore from the Styrian Erzberg mine was processed into valuable high-quality products. From 1860 onwards, this essentially smallscale industry came to a standstill, unable to compete with the larger-scale manufacturing that industrialization enabled elsewhere, and because of extensive deforestation and the resulting enormous rise in the price of charcoal as an important raw material.

In 1624, the main union, the Innerberger Hauptgewerkschaft, was founded, which secured and controlled the economy of the entire iron industry and iron marketing in the empire. The Innerberger Hauptgewerkschaft, as a trades union, existed until 1881 and was a predecessor of the Österreichisch-Alpine Montangesellschaft company, and thus also of Voestalpine AG, which exists today.

Water as a means of transport has a long tradition

Timber drifting, the floating of loose timber, was common, and the oldest and cheapest form of transport on long stretches of river. Dams were built in the upper reaches of the river and rakes in the lower reaches to catch the logs. Between 1567 and 1570, the well-known Tyrolean hydraulic engineer Hans Gasteiger built the largest timber rake in the Monarchy in Großreifling, which was in operation until it was destroyed by a flood in 1862. Tying the timber (for timber rafting), common from the end of the $19^{\text {th }}$ century, enabled up to $15 \mathrm{~m}^{3}$ (on the Salza) and $700 \mathrm{~m}^{3}$ (on the Danube) of round and sawn timber to be floated downstream at the same time, depending on the character of the river and the type of construction for which the timber was destined. The waterways lost importance as transport routes from 1873 onwards with the expansion of the Crown Prince Rudolf Railway and the import of Silesian hard coal for iron smelting, the expansion of the network of paths and roads, and the construction of hydroelectric power stations. Today, kayakers, rafters and other white-water sports enthusiasts spend their leisure time on the Enns and the Salza and enjoy the natural river landscapes.

In Großreifling, reminders of the region's significant past can be seen in the historic ensemble of buildings that comprises the Alter Kasten, the Neuer Kasten (a warehouse, then later a manor house), the Innerberger Getreidespeicher (grain silo) of 1771, together with the Austrian Forestry Museum Silvanum and the Nikolauskirche (Church of St. Nicholas, the patron saint of rafters, shipmen and sailors), Zimmerbütte Koblwaage (a huge scale for weighing large quantities of coal), and the remains of the Gasteiger Rechen (wooden rake / dam) in the Enns (Figure 4).

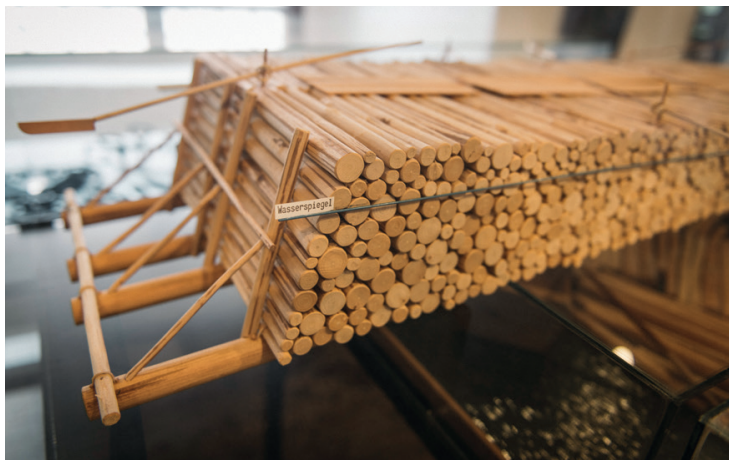

Figure 4 - Model of a timber raft in the Austrian Forestry Museum (C) Stefan Leitner - Gesaeuse - Mit Unterstützung von Bund, Land und EU (LEADER)

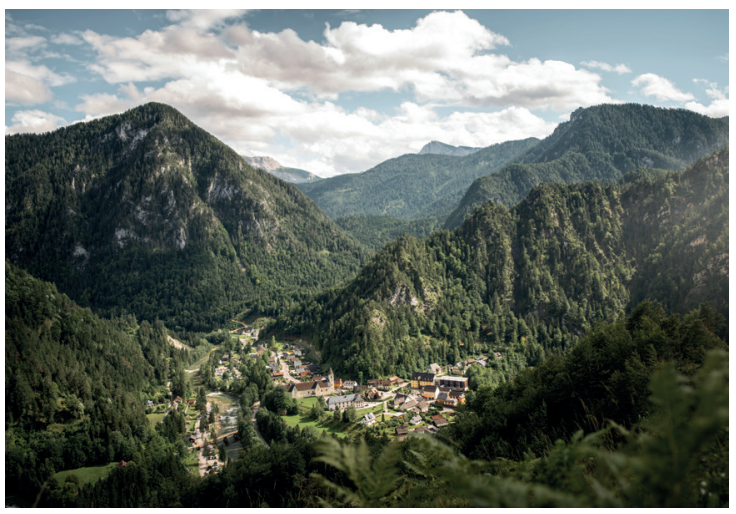

Figure 5 - Natural surroundings of the Nature Park municipality Wildalpen (C) Stefan Leitner - Gesaeuse - Mit Unterstütrung von Bund, Land und EU (LEADER)

\section{The future. The wild heart of Austria}

Austria's wild heart is located in the centre of the country, where the borders of three provinces (Upper Austria, Lower Austria and Styria) meet. For historical reasons and because the region is relatively remote from the provinces' urban agglomerations, it has remained fairly natural and relatively unfragmented. The altitude ranges from about $350 \mathrm{~m}$ to more than $2500 \mathrm{~m}$.

Quite extensive areas of natural mixed forests are found here, as is Austria's last remaining primeval forest (about 400 ha in Wilderness Area Dürrenstein). Patches of untouched forest are also located in Kalkalpen National Park, which is the largest protected forested area in Austria. The dominant type of forest is beech mixed with fir, spruce, maple, larch and other species in different proportions, depending on the site, altitude etc. The outstanding forests in the Northern Limestone Alps were recognized as Austria's one and only UNESCO natural World Heritage Site in 2017, as a European heritage site of ancient beech forests.

Because of the outstanding natural assets, it is not surprising that there are numerous protected areas (PAs) in this region. The protection status ranges from $\mathrm{NaPs}$ up to a strictly protected wilderness area (IUCN category Ia). Both Kalkalpen National Park and Gesäuse National Park are PAs in IUCN category 


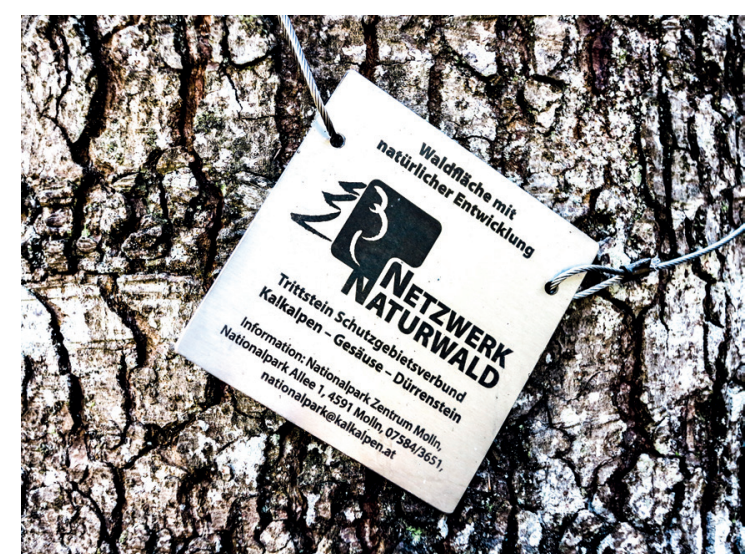

Figure 6-Recognition label for the Netzwerk Naturwald (C) Christian Scheucher

II. Additionally, there are several nature reserves, established by the federal laws of the three provinces.

2012 saw the start of cooperation between the three international PAs (Kalkalpen National Park, Gesäuse National Park and Wilderness Area Dürrenstein) to create a network of natural forests (Netzwerk Naturwald 2021), aimed at protecting and enhancing ecological connectivity (Figure 6). The approach and the first steps to establish a functional network of stepping stones beyond provincial borders was visionary and future-orientated (see Figure 7); it also had a posi- tive impact in the nomination process as a UNESCO world heritage site of ancient beech forests. Since the award by UNESCO, the ecological connectivity between the component parts and beyond has become a national and even international task. The natural world heritage of ancient and primeval beech forests of the Carpathians and other regions of Europe includes areas in Albania, Belgium, Bulgaria, Croatia, Germany, Italy, Romania, Slovakia, Slovenia, Spain and Ukraine. More information is available at: www.weltnaturerbebuchenwaelder.de.

The project itself: Netzwerk Naturwald connecting habitats - finding ways together

In 2020, the Styrian Eisenwurzen Nature and Geopark became the newest member of the network of natural forests. The $\mathrm{NaP}$ has the benefit of lying between the three high PAs - the two National Parks and the wilderness area. It can therefore help to improve the connectivity of the three PAs. For long-term preservation of biodiversity, breeding between populations of wild animals and plants is necessary. The project will ensure this interchange, via inter-connecting habitats.

Both inhabitants and visitors to the ancient cultural landscape will also benefit from the planned merging of biotopes, by finding ways of working together.

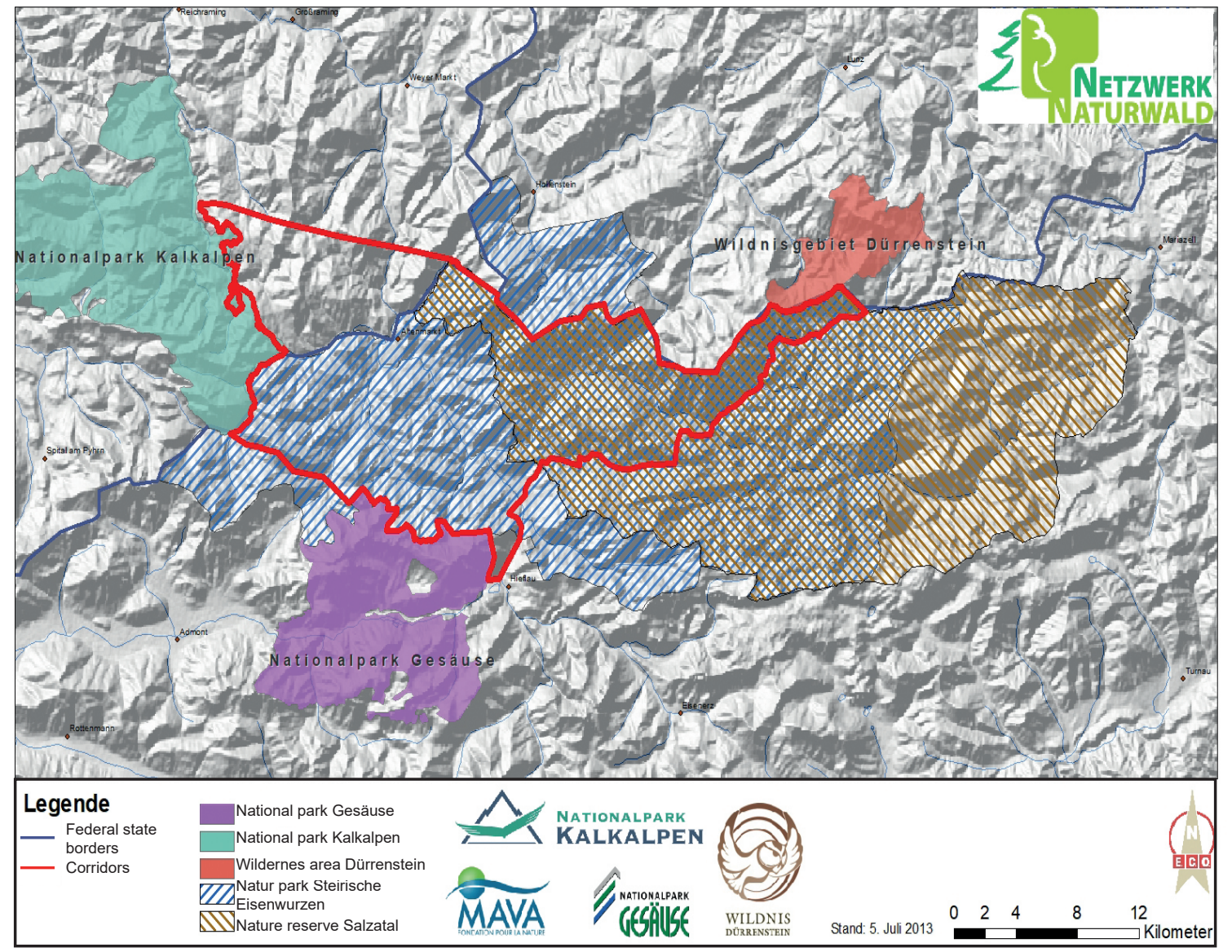

Figure 7 - Map of the connectivity corridor within the project area. Priority areas under nature conservation law (C) E.C.O. 
The objectives of the project are to:

develop and implement strategies for merging biotopes;

- initiate a cooperation committee;

increase awareness of the region's natural jewels;

- make clear the opportunities for regional development;

realize concrete pilot projects.

Within the three PAs, natural dynamic processes are still assured. However, the PAs are not large enough individually for many animals and plants to survive there in the long term. For the preservation of biodiversity, the possibility of migrating and mixing genetically with other populations is essential. Forest-dwelling animals need a functional network of natural forests to migrate between different habitats. Unfortunately, this network is not reliable everywhere, as human settlements, agriculture, roads and so on act as barriers for many species. In addition, some of the remaining forests are threatened by intense logging, which makes them unliveable for many species. Within the project area, there are outstanding natural forests in which the habitats are separated only by short distances. This provides a great opportunity for nature and for the region. By connecting the existing habitats, it is possible to create an outstanding compound of biotopes for Central Europe.

Synergies between the PAs and the history of the cultural area of Eisenwurzen (the latter being important in shaping some of the natural characteristics of the region) provide a unique potential.

\section{The contribution of the Nature and Geopark}

The Styrian Eisenwurzen connects the PAs. Geographically in the middle of them, the $\mathrm{NaP}$ offers the possibility of improving sustainable, close-to-nature, forest management, of re-connecting fragments of old-growth forest preserved in National Parks and Wilderness Area, as well as of integrating Natura 2000 sites into the area. It allows the strengthening of existing stepping stones and the establishment of new ones, to create ecological corridors. The $\mathrm{NaP}$ offers both natural old-growth beech forests and sustainably managed forests, which are managed to allow their coexistence to continue into the future. These characteristics and measures allow the region to contribute significantly to the targets of the 2030 biodiversity strategy, to re-establish green infrastructure, and to provide ecosystem services such as water purification, air quality, space for recreation, and climate mitigation and adaptation. Future activities will help to preserve the high quantity and variety of alpine forest habitats for generations to come (Figure 8). The area's outstanding ecological value will be the foundation for sustainable regional development within a green economy. The region will function as a green belt and lung in the middle of Europe.

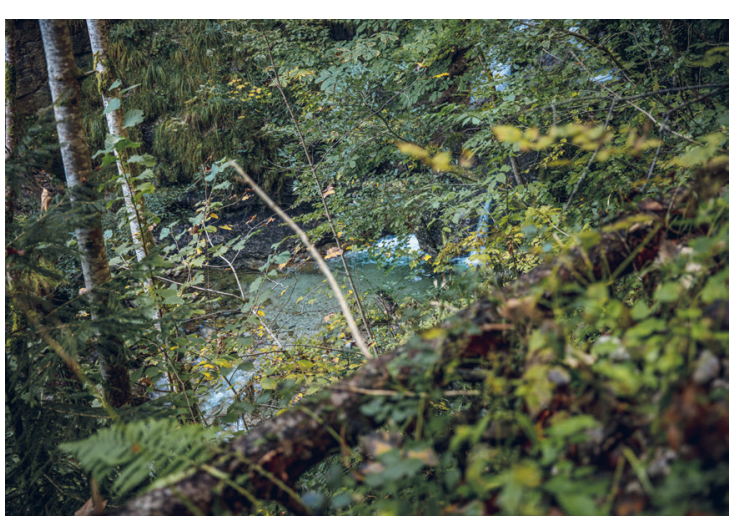

Figure 8 - Nature and forest (C) Thomas Sattler

The project region is shaped by the history of the Eisenwurzen cultural area, and its use by humans for more than 800 years. Even today, the region as a whole forms a single cultural and economic space. It touches three provinces, and $25 \mathrm{PAs}$ that together have a total area of more than 200000 ha. This natural environment is unique in the Alpine region and beyond, as demonstrated by earlier EU-funded projects such as Interreg greenAlps or Interreg ALPBIONET2030 - for background information, see: www.jecami.eu. These EU-financed projects focused especially on the $\mathrm{PAs}$, but not on the corridors between them. The $\mathrm{NaP}$ and the Styrian Eisenwurzen UNESCO Global Geopark connect these three PAs. The main objective is to enhance ecological permeability by providing sustainable connections between natural habitats - extensions of the ecological corridor between the PAs. This will be achieved by identifying the habitats of old-growth forests and protecting them, as well as by improving the ecological functionality of commercially managed forests. The measures will enable genetic exchange between isolated populations and ensure high long-term biodiversity. By involving various stakeholders and regional areas, different conservation and protection levels are targeted (including banning logging entirely in some areas). Management of the area as a whole thus includes various contractual models (for example, for the creation of stepping-stone biotopes, or for limiting the use of heavy plant), as is appropriate within a partly commercial forestry setting that also includes private landowners.

Future objectives within possible projects or joint activities:

1. Awareness raising at international, national and regional levels of the importance of old-growth forests, their contribution to biodiversity, and their provision of ecosystem services

2. Developing principals for nature-orientated forest management; agreeing and setting up contractual and funding models for nature conservation measures in forests

3. Screening for old-growth forests; selecting stepping-stone biotopes; identifying degraded forest stands for conversion to more natural forest habitats along the corridors of the ecological network 
4. Implementing protection of old-growth forest; conversion of degraded secondary forest stands; adapting forest management in accordance with the principles of nature-orientated forest management in the NaP.

\section{References}

BMNT 2018. Wie steht es um unseren Wald? Die Ergebnisse der Österreichischen Waldinventur des BFW.

Dowling, R.K. 2013. Global Geotourism - An Emerging Form of Sustainable Tourism. Czech Journal of Tourism 2(2): 59-79. DOI: $10.2478 /$ cjot-2013-0004

Dowling, R.K. \& D. Newsome (eds.) 2006. Geotourism. Butterworth-Heinemann, Oxford.

Global Geoparks Network 2017. About GGN. Available at: http://www.globalgeopark.org/aboutGGN/6398.htm (accessed 02/03/2021)

Global Geoparks Network 2020. What is a UNESCO Global Geopark? Available at: http://www. globalgeopark.org/aboutGGN/6398.htm (accessed 02/06/2020)

Gulas, O. \& H. Kollman 2016. Der Natur und Geopark Steirische Eisenwurzen. In: Hejl, E., H. Ibetsberger \& H. Steyrer (eds.), UNESCO Geoparke in Österreich. Natur- und Kulturerlebnisfübrer der Universität Salzburg: 129-165.

Hafner, F. 1979. Steiermarks Wald in Geschichte und Gegenwart. Wien.

Netzwerk Naturwald 2021. About the network and the benefits. Available at: https://www.netzwerk-naturwald.at/index.php/en-GB/ (accessed 02/02/2021)

Nitsch, C. 2019. 6.1 Northern Limestone Alps. In: Plassmann, G., Y. Kohler, C. Walzer, J. Kahlen, C. Bei- glböck, K. Svadlenak-Gomez et al., Alpbionet2030. Integrative Alpine wildlife and habitat management for the next generation: 70-71. Available at: https:// www.alpine-space.eu/projects/alpbionet2030/en/ project-results (accessed 01/03/2021)

Pásková, M. 2012. Environmetalistika cestovního ruchu (Tourism Environmentalism). Czech Journal of Tourism 1(2): 77-113.

VNÖ 2021. Was ist ein Naturpark. Graz: Verband Naturparke Österreichs. Available at: https://www. naturparke.at/vnoe/verband-der-naturparke-oesterreichs/was-ist-ein-naturpark/ (accessed 02/10/2017)

UNESCO 2020. What is a UNESCO Global Geopark? Available at: http://www.unesco.org/new/ en/natural-sciences/environment/earth-sciences/ unesco-global-geoparks / frequently-asked-questions/what-is-a-unesco-global-geopark/ (accessed 02/06/2020)

\section{Authors}

\section{Oliver Gulas}

Styrian Eisenwurzen Nature and Geopark, Austria. E-mail: oliver.gulas@eisenwurzen.com, www.eisenwurzen.com

\section{Veronika Frank}

Austrian Forestry Museum, Großreifling, Landl, Austria. E-mail: tourismus@landl.gv.at, www.forstmuseum.at

\section{Christoph Nitsch}

Kalkalpen National Park, Molln, Upper Austria, Austria. E-mail: christoph.nitsch@kalkalpen.at, www. kalkalpen.at
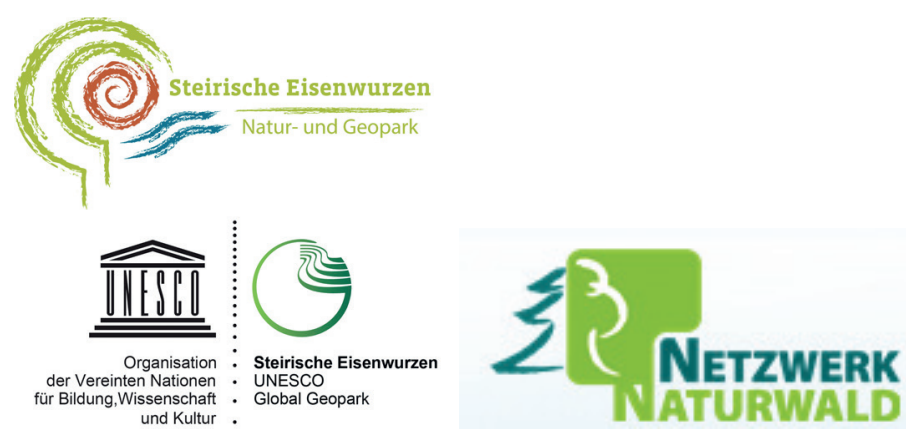